\title{
periferio
}

\section{DA FOTOGRAFIA AO MEME, PAULO FREIRE ATRAVÉS DAS SUAS IMAGENS NA INTERNET}

\author{
Aristóteles de Paula Berino1 \\ Universidade Federal Rural do Rio de Janeiro \\ Marcélia Amorim Cardoso ${ }^{2}$ \\ Universidade Federal Rural do Rio de Janeiro
}

\section{Resumo}

O legado intelectual de um autor se transforma com as sucessivas releituras e os novos significados atribuídos à sua obra. Em uma época em que a cultura visual multiplica as representações de um autor em numerosas telas, seu legado também é atingindo por essas intervenções. A partir de algumas imagens de Paulo Freire que circulam pela internet, procuramos pesquisar como essas aparições interferem nos sentidos que atribuímos à sua herança intelectual. A importância da obra de Paulo Freire também é disputada em ambientes virtuais, uma tessitura sobre sua existência que discutimos no artigo. Portanto, o que sabemos sobre Paulo Freire, tudo que acreditamos constituir seu pensamento e legado, não se realiza apenas através da herança presente em seus livros. Existe ainda um Paulo Freire estético, resultado de muitas e variadas representações criadas e que também projetam a sua obra. Entre essas tantas aparições, existem ainda aquelas que são propriamente visuais: fotos, desenhos, trabalhos artísticos e até memes. Nesse artigo nos interessa exatamente esse Paulo Freire pictórico.

Palavras-chave: Paulo Freire; cultura visual; internet

\footnotetext{
1 Professor associado I da Universidade Federal Rural do Rio de Janeiro no Departamento de Educação e Sociedade do Instituto Multidisciplinar (Campus Nova Iguaçu) e no Programa de Pós-Graduação em Educação, Contextos Contemporâneos e Demandas Populares (PPGEducUFRRJ). aristotelesberino@yahoo.com.br

2 Doutoranda em Educação pela Universidade Federal Rural do Rio de Janeiro -UFRRJ. myramarcel@yahoo.com.br
} 


\title{
periferio
}

FROM PHOTOGRAPHS TO MEMES, PAULO FREIRE THROUGH HIS IMAGES ON THE INTERNET

\begin{abstract}
The intellectual legacy of an author is transformed by the successive rereading's and the new meanings attributed to his work. At a time when visual culture multiplies the representations of an author on numerous screens, his legacy is also hit by these interventions. Based on some of Paulo Freire's images that circulate on the Internet, we seek to investigate how these apparitions interfere on the meanings we attribute to his intellectual heritage. The importance of Paulo Freire's work is also disputed in virtual environments - a texture about his existence that we discuss in the article. Therefore, what we know about Paulo Freire, everything that we believe constitutes his thought and legacy, is not realized only through the inheritance present in his books. There is still an aesthetic Paulo Freire, the result of many and varied representations created and that also project his work. Among these many apparitions, there are still those that are properly visual: photos, drawings, works of art and even memes. In this article we are interested exactly in this Paulo Freire pictorial.
\end{abstract}

Keywords: Paulo Freire; visual culture; internet 




\section{DE LA FOTOGRAFÍA AL MEME, PAULO FREIRE A TRAVÉS DE SUS IMÁGENES EN INTERNET}

\section{Resumen}

El legado intelectual de un autor se transforma con las sucesivas relecturas y los nuevos significados atribuidos a su obra. En una época en que la cultura visual multiplica las representaciones de un autor en numerosas pantallas, su legado también es alcanzando por esas intervenciones. A partir de algunas imágenes de Paulo Freire que circulan por internet, buscamos investigar cómo esas apariciones interfieren en los sentidos que atribuimos a su herencia intelectual. La importancia de la obra de Paulo Freire también se disputa en ambientes virtuales, una tesitura sobre su existencia que discutimos en el artículo. Por lo tanto, lo que sabemos sobre Paulo Freire, todo lo que creemos constituir su pensamiento y legado, no se realiza sólo a través de la herencia presente en sus libros. También existe un Paulo Freire estético, resultado de muchas y variadas representaciones creadas y que también proyectan su obra. Entre esas tantas apariciones, existen todavía aquellas que son propiamente visuales: fotos, dibujos, trabajos artísticos e incluso memes. En este artículo nos interesa exactamente ese Paulo Freire pictórico.

Keywords: Paulo Freire; cultura visual; internet 


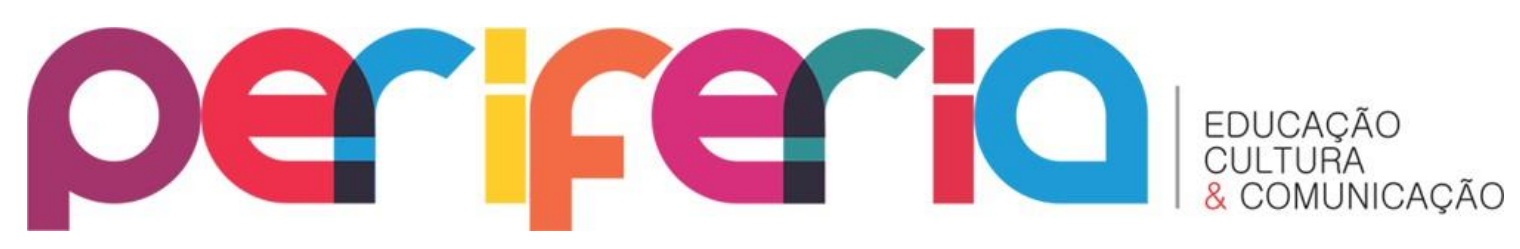

Eu gostaria de ser lembrado como um sujeito...

(FREIRE, 2004, p. 329)

Como as imagens são usadas? O que fazemos com as imagens? $O$ que as imagens fazem com a gente? Faz até mesmo sentido falar da imagem? (WULF, 2013, p. 21)

Em uma conversa com o repórter Edney Silvestre, em maio de 1997, dias antes da sua morte, Paulo Freire é provocado a responder a propósito da sua imagem para a posteridade: "como o senhor quer ser lembrado?". A frase que usamos como a primeira epígrafe do nosso texto segue assim: "um sujeito que amou profundamente o mundo e as pessoas, os bichos, as árvores, as águas, a vida". Interrompemos propositalmente a frase na epígrafe porque gostaríamos de começar exatamente afirmando a impossibilidade de alguém projetar integralmente a sua própria imagem, mesmo Paulo Freire. A imagem de uma vida foge ao governo de cada pessoa.

Paulo Freire responde de modo sentimental ao desafio de declarar como gostaria de ser visto postumamente, propondo para si mesmo uma representação lírica, alguém que amou o mundo, as pessoas e as coisas. Mas não importa. A ideia que fazemos dele é resultado de muitas tessituras, incontroláveis para Paulo Freire. Existem a sua obra, suas miragens e leituras tão diversas que multiplicam sua vida em muitas e virtuais existências. Entre essas tantas aparições de Paulo Freire, existem ainda aquelas que são propriamente visuais: fotos, desenhos, trabalhos artísticos e até memes. Nesse artigo nos interessa exatamente esse Paulo Freire pictórico.

Portanto, o que sabemos sobre Paulo Freire, tudo que acreditamos constituir seu pensamento e legado, não se realiza apenas através da herança presente em seus livros. Existe ainda um Paulo Freire estético, resultado de muitas e variadas representações criadas e que também projetam a sua obra. Depois da sua partida, 20 anos atrás, Paulo Freire tem uma vida animada não exclusivamente por nossas impressões a respeito do que escreveu, mas 


\section{periferio}

também porque sua existência se reproduz através de imagens. Esse é o assunto da nossa discussão aqui: a existência plástica de Paulo Freire. Especificamente, qual Paulo Freire existe através das suas imagens na internet?

Paulo Freire construiu um pensamento e uma prática educacional que influenciou concepções e ações educacionais no país e em diversas partes do mundo. Rompendo com a lógica hierárquica e discriminatória de um conhecimento fundamentado em bases opressoras, propõe uma pedagogia crítica que concebe o conhecimento, as práticas pedagógicas e as relações educativas, a partir da correspondência e da troca, da busca, da constituição das subjetividades e da prática social e política. Através desses caminhos (e descaminhos) educacionais o ser humano se educa e educa os outros em comunhão e com um saber que não é único e nem privilegiado. Um saber que é local, histórico, cotidiano; construído na experiência e, principalmente, no diálogo.

Nosso interesse pela obra de Paulo Freire e o desafio de discutir seu legado pelo prisma da contemporaneidade motivou uma investigação e uma conversa a respeito da sua presença atual através de algumas das suas imagens projetadas na internet, rede visual onde sua obra também partilha e produz renovados sentidos. Então, pensar a existência de um Paulo Freire cuja vida intelectual é representada através do mundo visual e digital da internet, discutindo como algumas dessas imagens atribuem múltiplos sentidos ao seu legado, intercedendo no significado contemporâneo da sua obra, é o que pretendemos desenvolver aqui.

Imagem, do latim imago, significa representação, forma, imitação, aparência ${ }^{3}$. Atividade humana presente desde as representações nas cavernas, a imagem participa das várias formas de comunicação: antes produzida com a intenção de cunhar o mágico-religioso em esculturas ou pinturas, em processos catárticos, depois com o propósito de imortalizar o mortal, fazê-lo

3 Cf Dicionário Priberam da Língua Portuguesa. Disponível em: <http://www.priberam.pt/DLPO/IMAGEM>. Acesso em 28 jul. 2016. 


\section{periferio}

presente na ausência. As tecnologias conquistadas puderam ampliar e variar este uso nas sociedades urbanas e industriais, como por exemplo, a fotografia e o cinema.

As imagens carregam memórias, entendimentos, sentimentos, referências, instigam a imaginação, expõem uma realidade e concepções de mundo. Podem comunicar substituindo palavras, como Paulo Freire (1994) relata, em Educação como Prática da Liberdade, quando mostrou a utilização de imagens, nos chamados Círculos de Cultura, feitas pelo artista Francisco Brennand: dez imagens, "dez situações existenciais 'codificadas', capazes de desafiar os grupos e levá-los pelas suas 'decodificação' as compreensões” do conceito de cultura. Ou seja, o chamado "Método Paulo Freire" de alfabetização é também um método imagético.

As imagens, implicitamente, trazem signos e significados associados a um conceito, uma concepção de mundo, uma forma de ver o objeto representado, seja por aquele que o vê, ou aquele que o produz, e está profundamente mediada pela cultura. Portanto, a imagem não representa a realidade estática, mas uma realidade constantemente (re)produzida pelos sujeitos. Apresentando, reapresentando, ou representando 'os mundos' como cada um os vê, evocando o que ou quem não está presente. Recriando sua existência de maneiras diversificadas e singulares.

A modernidade inaugura a imagem como veículo de difusão amplamente popular de signos, símbolos e informações, presente em inúmeros eventos do cotidiano das pessoas, como mídias, publicidade ou comunicação. $\mathrm{Na}$ modernidade avançada, os meios visuais endossados pelo capitalismo, incrementam ainda mais a construção de uma cultura de hiperveiculação de imagens. Muitas das imagens de Paulo Freire encontradas na internet já são conhecidas porque foram antes impressas em livros. Com a cibercultura, essas imagens, contudo, se multiplicam em razão dos muitos usos e variedade de suportes tecnológicos: o computador, o tablet e o smartphone, por exemplo. Nas redes sociais, entre elas, o Facebook, são compartilhadas por numerosos usuários. As imagens de Paulo Freire estão 




disponíveis para visualizações em uma proporção que ele não conheceu ao longo de sua vida. São postadas com pretensões variadas e tampouco trata-se de uma posse especializada. Escapam dos arquivos e das biografias ilustradas, dirigidas por estudiosos, de manipulação ou consumo restrito, para um trânsito aberto, nas mãos de qualquer pessoa, pode-se assim dizer.

As imagens de Paulo Freire apresentadas aqui, em número de sete, foram extraídas de páginas diversas da internet. São imagens facilmente localizadas e qualquer estudante de Pedagogia irá se deparar com algumas delas fazendo pesquisas na internet, em sites de conteúdo sobre educação, blogs, páginas de informação e notícias ou simplesmente acompanhando o seu feed de notícias de uma rede social. Além das imagens selecionadas de Paulo Freire, usamos outras ainda, em número de quatro, na elaboração da nossa discussão. A proposta não é a realização de análises sumárias e finalizadas das imagens que selecionamos. Concordamos com Vicente (2000, p.147), quando diz que "interpretações diversas, mesmo aquelas produzidas por sujeitos que participam do mesmo tempo histórico e mesmo grupo cultural, são capazes de recriar sentidos e significados".

É importante enfatizar que nossa pretensão também "não consiste certamente em tentar encontrar uma mensagem pré-existente, mas em compreender que significações determinada mensagem, em determinadas circunstâncias, provoca aqui e agora, sempre tentando destrinçar o que é pessoal do que é coletivo" (JOLY, 1996, p. 47). Compreendendo que as imagens exercem várias funções sociais, políticas e culturais, possuem, assim, razões diversas para existir. Manifestando sentidos e valores simbólicos, tratam-se de realizações mediadas pelos códigos nelas presentes, como cores, texturas e contextos. Elas se dizem e dizem o mundo, através dos olhares que as interpretam de modo multirreferenciado.

Pillar (2003, p. 74) lembra que "o nosso olhar não é ingênuo, ele está comprometido com nosso passado, com nossas experiências, com nossa época e lugar, com nossos referenciais". Impregnada de experiências anteriores, associações, lembranças e fantasias, nossa leitura de imagens não vê o real, 


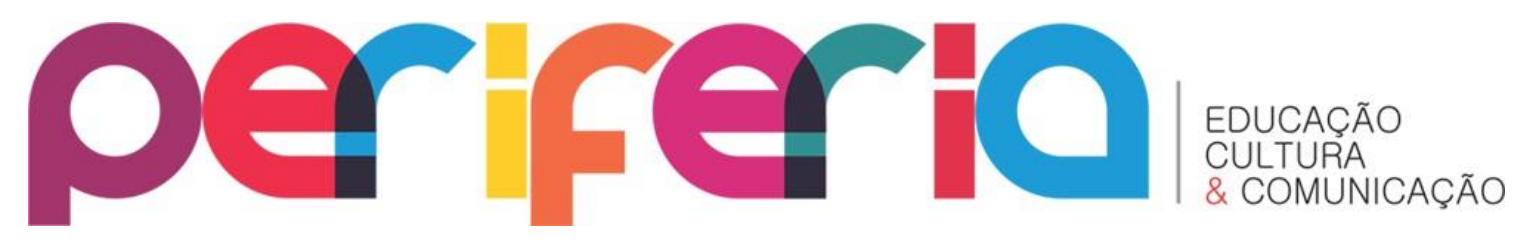

mas aquilo que passamos por um filtro, tornando este ato "uma aventura em que a cognição e a sensibilidade se interpenetram na busca por significados, lançando múltiplos olhares sobre um mesmo objeto” (PILLAR, 2011, p. 78), construindo e recriando novos/outros sentidos para aquilo que se vê, mas que também se percebe, se lembra, se afeta.

A primeira imagem de Paulo Freire que apresentamos para a nossa discussão foi selecionada em uma pesquisa no Google Imagens. É um dos seus primeiros retratos que aparece.



Trata-se de uma imagem do seu período no exílio, nos anos 70. É bem característica de outras tantas imagens de intelectuais próximos à sua geração. Como exemplo, vale mostrar uma imagem de Jean-Paul Sartre que contém alguns elementos que estão presentes também no retrato de Paulo Freire. 


\section{periferio}

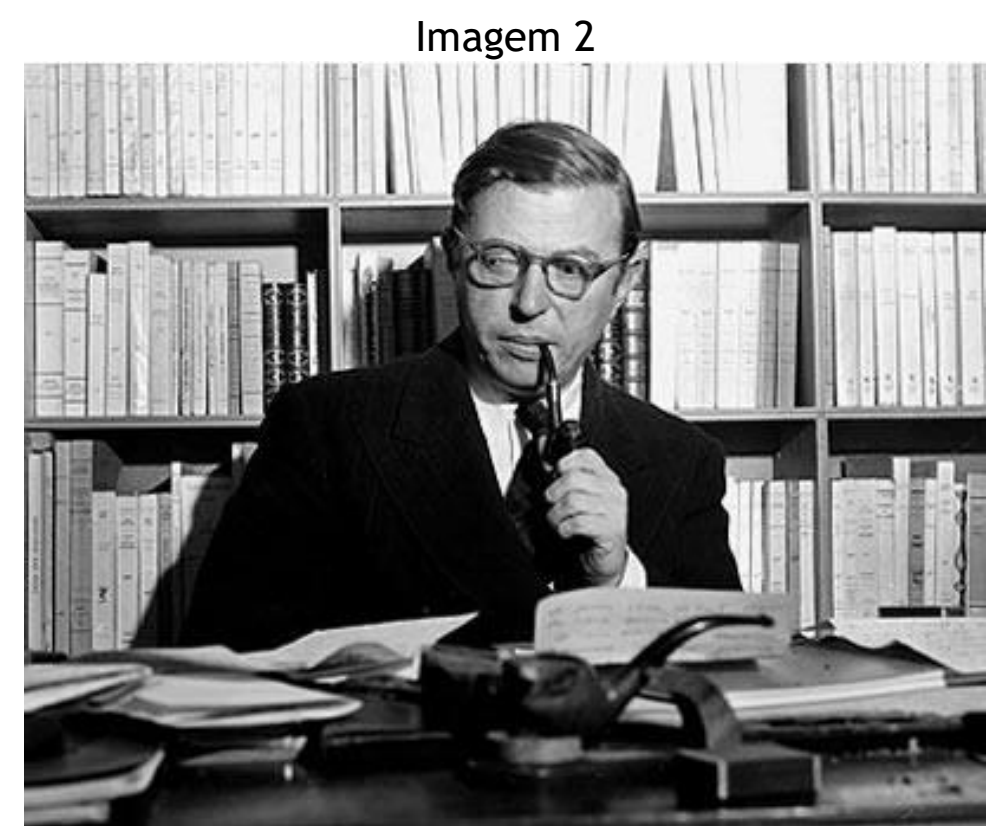

Fonte: http://lounge.obviousmag.org/ruinas/2013/03/a-erasartre.html.jpg?v=20161113081809

Nos dois personagens há uma imagem de credibilidade e elegância, conferida pelo ambiente, a roupa e o próprio corpo. Os livros na estante, a vestimenta sóbria, a expressão no rosto, o gesto com as mãos segurando cigarro e cachimbo e também os óculos, são elementos que nos transmitem, no seu conjunto, a destacada imagem de intelectual prestigioso, apreciável e moderno. Em Paulo Freire, a barba também é um elemento observável como manifestação de plenitude e maturidade. A propósito, Paulo Freire, a julgar por um diálogo com o educador Sérgio Guimarães, tinha plena consciência desse jogo entre aparência e identidade: "Comecei a usar a barba, em 1969 (...), talvez pudesse dizer hoje de forma muito simples: eu sou também a minha barba (risos), de maneira que se eu tirar a minha barba hoje, grande parte do mundo me desconhece" (FREIRE; GUIMARÃES, 2000, p. 56). Paulo Freire demonstra nítida percepção da relação inseparável, mesmo para um intelectual, entre a pessoa e sua imagem em uma sociedade global e mediática, cuja projeção acontece não apenas em razão das andanças pelo planeta, mas através da circulação mundializada das suas publicações e também da sua existência em uma fotografia. 

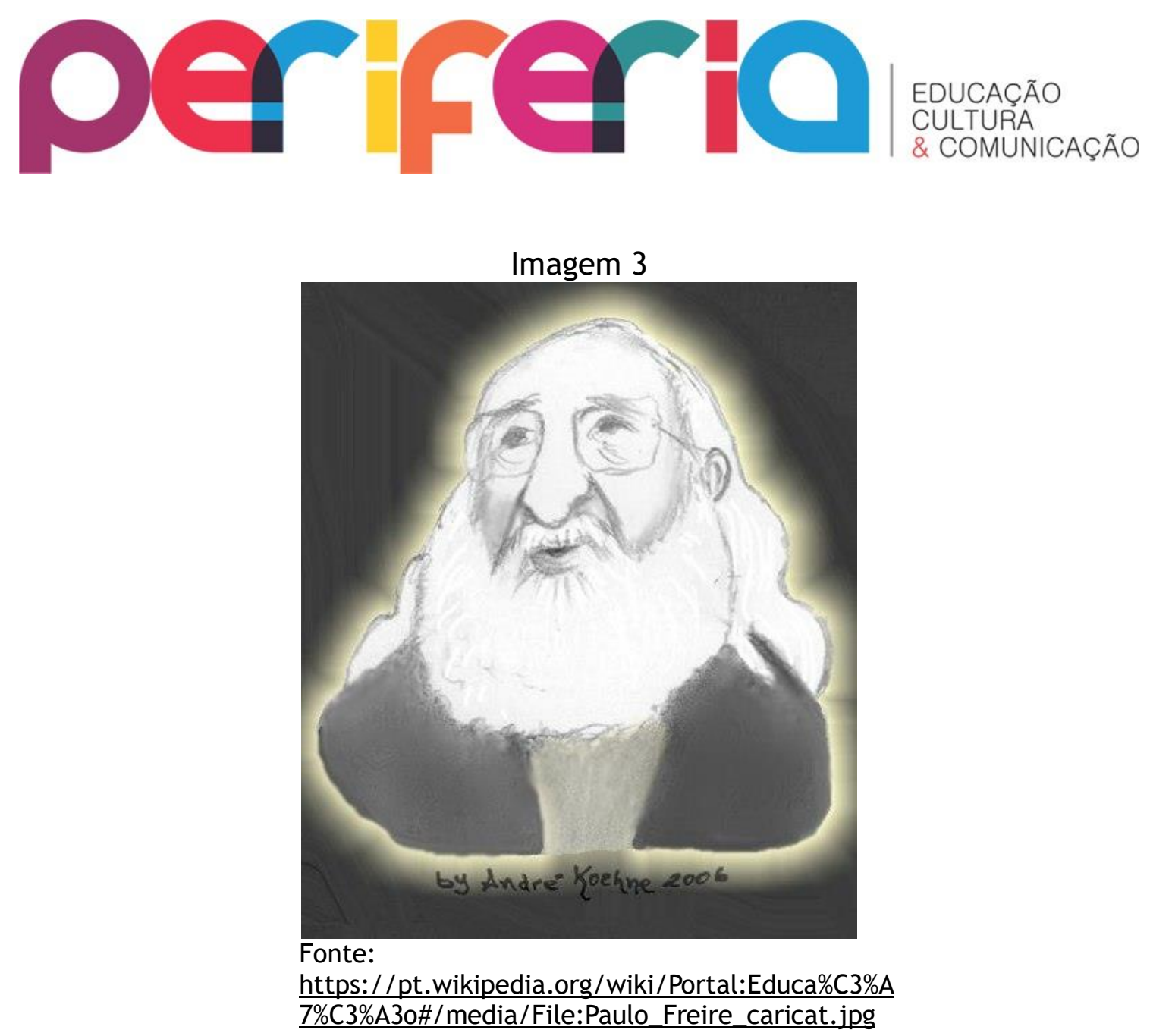

A segunda imagem de Paulo Freire é um retrato artístico feito por André Koehne, extraído do Portal Educação da Wikipédia, na coluna "imagens em destaque". Visitando a página, a visualização superficial do seu conteúdo logo encontrará essa imagem chamando atenção para Paulo Freire. Ao clicar nela é possível observá-la em uma dimensão maior. Chama a atenção uma aparente aura luminosa que envolve toda a sua figura, que pode ser comparada à representações religiosas comumente encontradas na popular iconografia cristã. Ao pesquisarmos as imagens de "santos católicos", no Google, escolhemos a imagem abaixo, como exemplo, para mostrar como essa associação pode ocorrer: 


\section{periferio}

Imagem 4

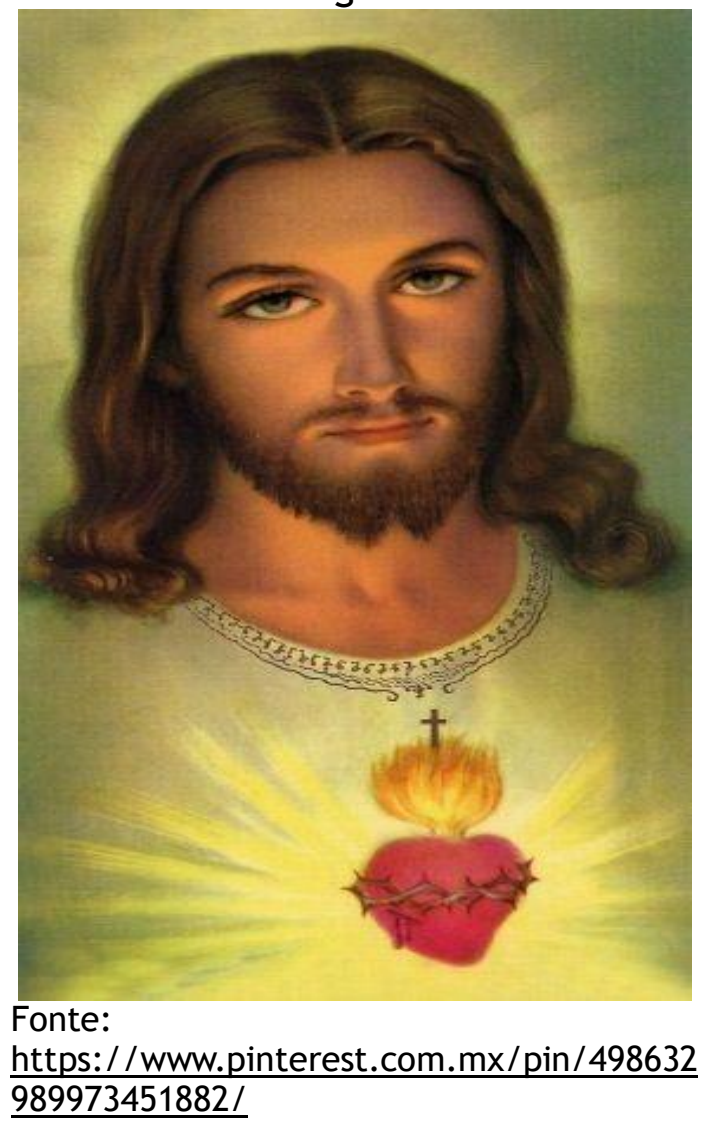

O resplendor que contorna o retrato de Cristo confere à sua existência um atributo divino que reconhecemos prontamente ao olhar sua figura. A representação visual cristã é uma pedagogia que nos acostumou com a associação dos seus personagens com uma auréola que circunda suas cabeças e identificamos com a experiência do sagrado. A luminosa figura de Paulo Freire projeta a mesma significação de uma personalidade respeitável e venerável, sobre-humana. Uma imagem divina de Paulo Freire beneficia-se ainda do fato de ter se declarado enfaticamente cristão, tantas vezes, inclusive, nos seus escritos. Mas, especialmente, o que importa aqui é a consequente sugestão de que a sua concepção de educação é redentora, um caminho bem-aventurado e exclusivo, cuja fidelidade precisa ser vigiada e o desvio evitado. No limite, trata-se de uma imagem que canoniza Paulo Freire e faz ver também sua obra como uma doutrina. 




É evidente que o reconhecimento adquirido por Paulo Freire, em razão das suas contribuições para o pensamento educacional nas últimas décadas do século XX e, especialmente, para a educação popular, para movimentos sociais diversos e práticas políticas emancipatórias em vários países, é inegavelmente merecido. Influência que permanece atual, inclusive. As homenagens têm sentidos diversos, importante observar. Nem sempre se trata de uma consagração para conferir à sua obra uma permanência inviolável, ou seja, impossível de tocada, apropriada e transformada também.

A terceira imagem de Paulo Freire que destacamos é uma escultura da artista plástica sueca Pye Engstron. Nela aparecem sete personalidades, da direita para a esquerda: Elise Ootesen-Jensen, Paulo Freire, Sara Lidman, Mao Tse-Tung, Angela Davis, Georg Borgström e Pablo Neruda.

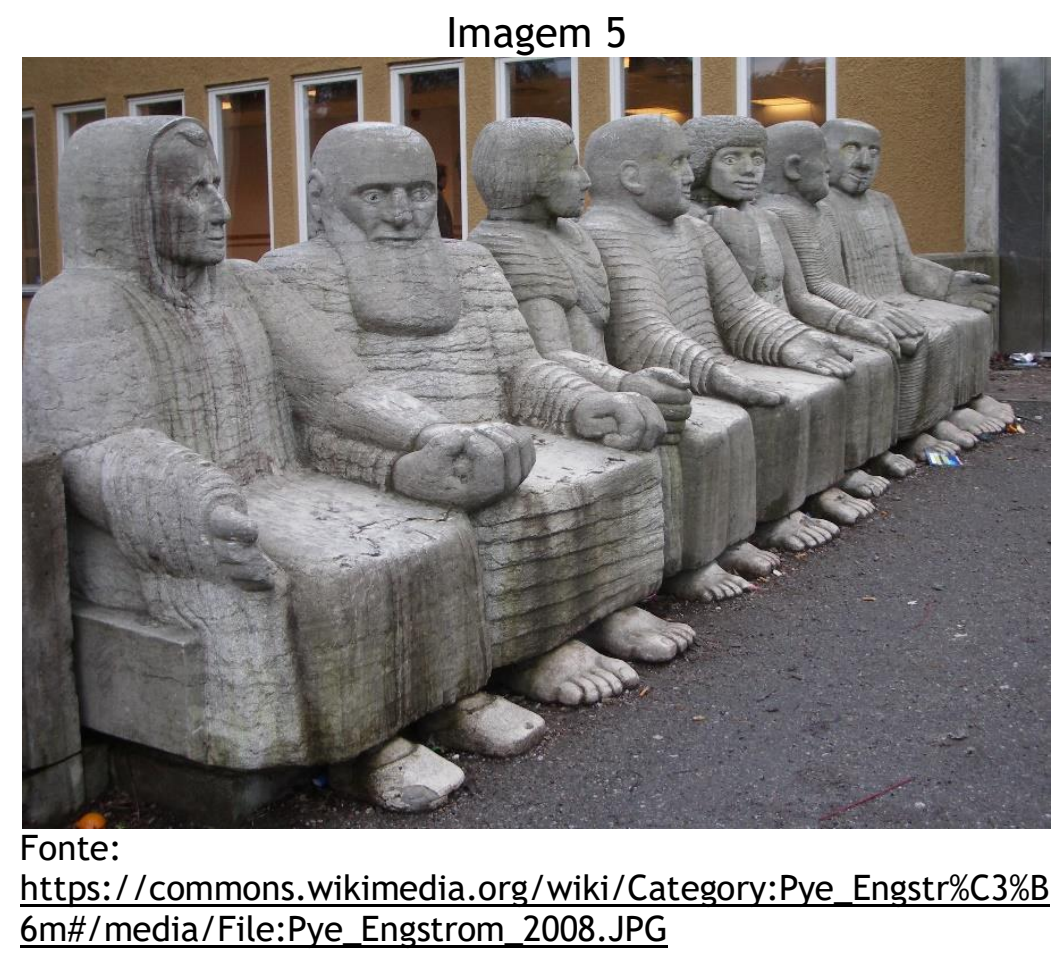

Entre as imagens de Paulo Freire, essa é uma das mais difundidas. É possível encontrá-la em publicações biográficas e também na internet. A versão que usamos foi extraída da página de Pye Engstron na Wikmedia, mas pode ser encontrada também no acervo virtual de imagens do Instituto Paulo 


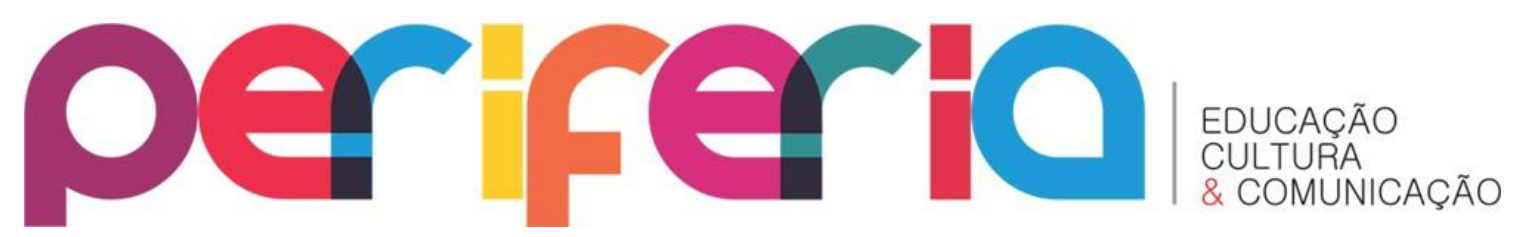

Freire. Entre os personagens da escultura, três são suecas e as demais de outras nacionalidades. Todas são de destacados ativistas políticos em diferentes áreas de atuação. Ao lado dos demais, por associação, cada indivíduo adquire a relevância de ter a sua existência dignificada pertencendo ao seleto grupo. Ou seja, aqui o coletivo soma à importância individual. Mas existe também um elemento extraordinário na imagem que precisa ser notado. A solidez e estética da escultura nos rementem visualmente a outras tantas imagens petrificadas, como a encontrada, por exemplo, na imagem 6, em outro conjunto de personagens, no templo de Abu Simbel, construído no Egito Antigo.

Imagem 6



Fonte: https://h6.googleusercontent.com/-

uV2F8qKAm3Q/TWkt0xEZogl/AAAAAAAAAAg/_7hX07pHoF0/s16

00/e1blog.png

$\mathrm{Na}$ verdade, as quatro esculturas, de vinte metros de altura, representam o mesmo faraó Ramsés II (séc. XIII a.C.), em quatro fases diferentes de sua vida. O que gostaríamos de observar é a relativa ambiguidade que cercam muitas imagens celebratórias de Paulo Freire, em razão dos valores e concepções esteticamente presentes. A imagem em uma escultura sugere um reconhecimento que deve ser suficientemente durador, 


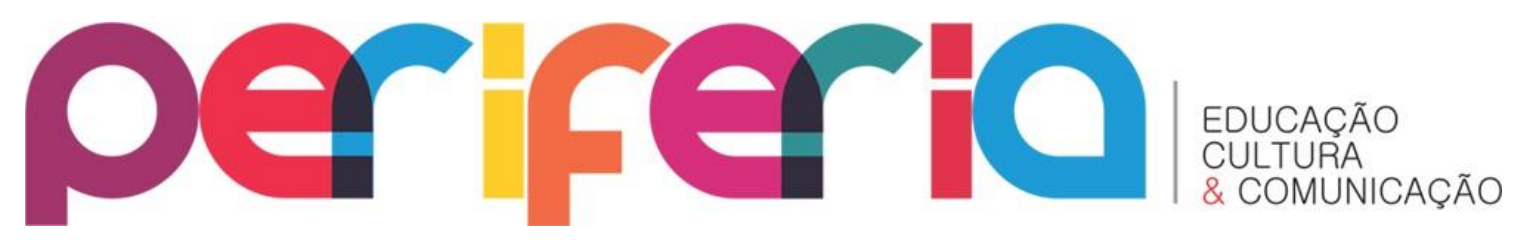

senão uma perpétua lembrança para outras gerações. Imagens como as de um Ramsés II, mesmo danificadas, nos alcançam até hoje, milênios após a sua edificação. Ao encontrar uma imagem de Paulo Freire como escultura, ao lado de outros personagens também "memoráveis", alguém que pesquisa sua vida e obra verifica a admissão da sua suprema relevância. Mas para um leitor tardio dos seus trabalhos, qual Paulo Freire procura? Pesquisa por um Paulo Freire eternizado no século XX ou gostaria de saber sobre um autor vivo, atualizado diante dos problemas do contemporâneo? Com certeza, os tempos se misturam e não devem (não podem) ser separados de forma absoluta. Mas imagens mais memoráveis de um autor, assim como a escultura de um faraó perpetuado, podem pedagogizar o nosso olhar na direção de uma admiração enrijecida e, no limite, desumanizada. Ou seja, um autor que sobrevive ao tempo e que o próprio tempo não transforma. Portanto, mesmo que não premeditado pela autora da obra, existe uma recorrente partilha e visualização da imagem de Paulo Freire como escultura que funciona também como uma veneração e uma adoração, enfim, de testemunho de uma dignidade acima da desejável interpelação crítica que devemos submeter todo e qualquer autor e/ou personalidade pública, inclusive para a sua atualização, ou seja, para sua acolhida e recepção em renovado contexto, as sociedades que mudam através da história.

A imagem 7, a quarta de Paulo Freire que destacamos, está também entre as mais difundidas dele hoje. Está presente no verbete Paulo Freire, da Wikipedia, e na pesquisa de imagens sobre ele no Google aparece também entre as primeiras. 


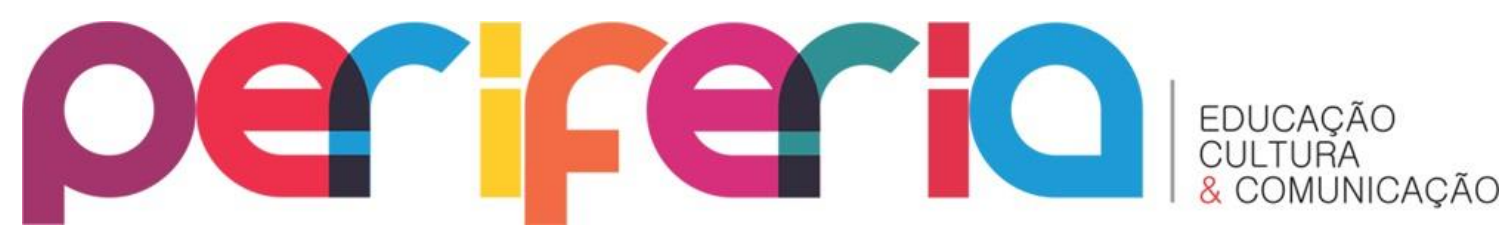

Imagem 7

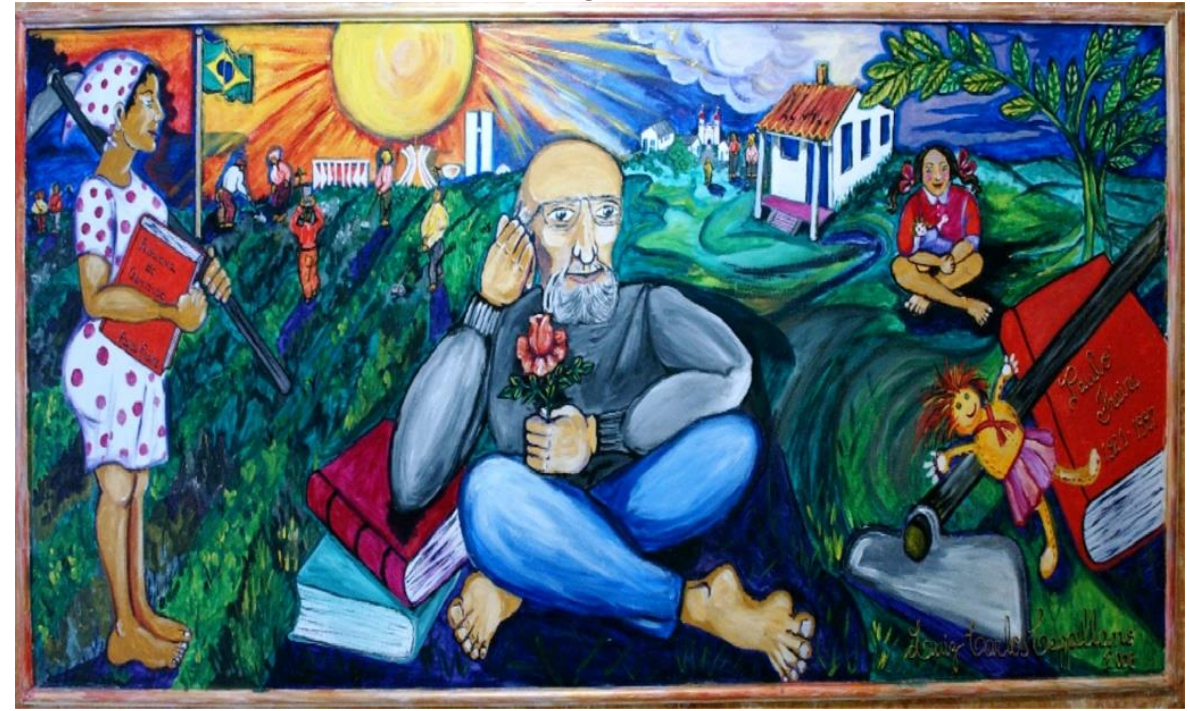

Fonte:

https://upload.wikimedia.org/wikipedia/commons/f/fd/Painel.Paulo.Fre ire.JPG

A obra é um painel, de $1,00 \mathrm{~m} \times 1,50 \mathrm{~m}$, que o artista Luiz Carlos Cappellano produziu, em 2008, para o prédio do CEFORTEPE - Centro de Formação, Tecnologia e Pesquisa Educacional "Prof. Milton de Almeida Santos", da Secretaria Municipal de Educação de Campinas, no estado de São Paulo. Em termos artísticos, é uma pintura naïf. Com numerosos elementos, a imagem contém uma narrativa sobre a trajetória de Paulo Freire como intelectual das classes populares. Observamos o cotovelo de Paulo Freire apoiado sobre dois livros, mas os pés descalços, assim como a mulher camponesa ao seu lado. Ela segura em uma das mãos um volume do emblemático Pedagogia do Oprimido enquanto segura uma enxada com a outra. Existe uma correspondência entre os dois personagens. A marcante presença dos elementos associados à natureza visto na imagem é contrastada com os elementos do trabalho e da cultura que a transformam também. Não se trata de uma composição absolutamente espontânea do autor. Há uma interessante homologia no painel de Capellano em relação ao trabalho de codificação e descodificação proposto com as fichas de cultura usadas no “método de alfabetização" de Paulo Freire. Inclusive, se lembrarmos os 


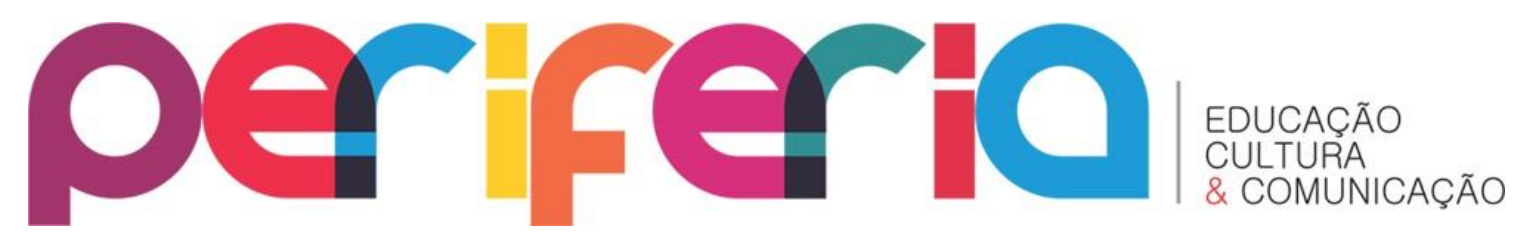

desenhos originais do artista Francisco Brennand feitos para Paulo Freire, a identidade visual é ainda mais nítida, como no exemplo abaixo.



Fonte:

http://forumeja.org.br/sites/foru meja.org.br/files/08brennand.jpg

Assim como as fichas constituíam um desafio visual ao alfabetizando, o painel de Capellano também propõe um desvelar de Paulo Freire através das muitas imagens, vamos assim dizer, que formam o desenho. Entre as tantas imagens que podemos encontrar de Paulo Freire na internet, sem dúvida, trata-se de uma das mais significativas na perspectiva de retratar sua identidade de educador popular, remetendo o internauta às campanhas de alfabetização de adultos que dirigiu nos anos sessenta, entre populações rurais, no nordeste. Trata-se da face mais conhecida e romantizada de Paulo Freire e existem motivos suficientes para isso, com certeza. No entanto, é importante lembrar que o legado de Paulo Freire é mais amplo e sua trajetória posterior, no Chile, nos Estados Unidos, na Europa, na África e ainda como Secretário de Educação da cidade de São Paulo (1989-91) também constituem sua vida e obra, inseparável da sua importância como autor. Não estamos querendo dizer que "faltou" mais alguma coisa na obra de Castellano. Não é essa questão. Todo e qualquer interessado na obra de Paulo 




Freire deve fazer esse trabalho de pesquisa mais abrangente. 0 que estamos observando, a partir das suas diferentes imagens na internet, é que cada imagem de Paulo Freire tem um endereçamento na apresentação que fazem, tecendo sentidos no amplo imaginário que existe sobre ele, sobre sua relevância e pertinência na história da educação, mas também agora, na memória e na utopia.

A imagem 9, a quinta de Paulo Freire que apresentamos, tem duas características bem distintas das anteriores. Até agora usamos uma reprodução fotográfica e três cópias digitais da figura de Paulo Freire em trabalhos artísticos. A imagem agora selecionada saltou das ruas para a internet. E mais, nela não existe propriamente um retrato feito ou desenhado de Paulo Freire. Trata-se da reprodução de uma imagem fotográfica em que ele é citado, mas não é mostrado de modo pictórico. No entanto, de certo modo, uma imagem de Paulo Freire é formada para quem lê o que está escrito na faixa e no contexto da sua exibição.

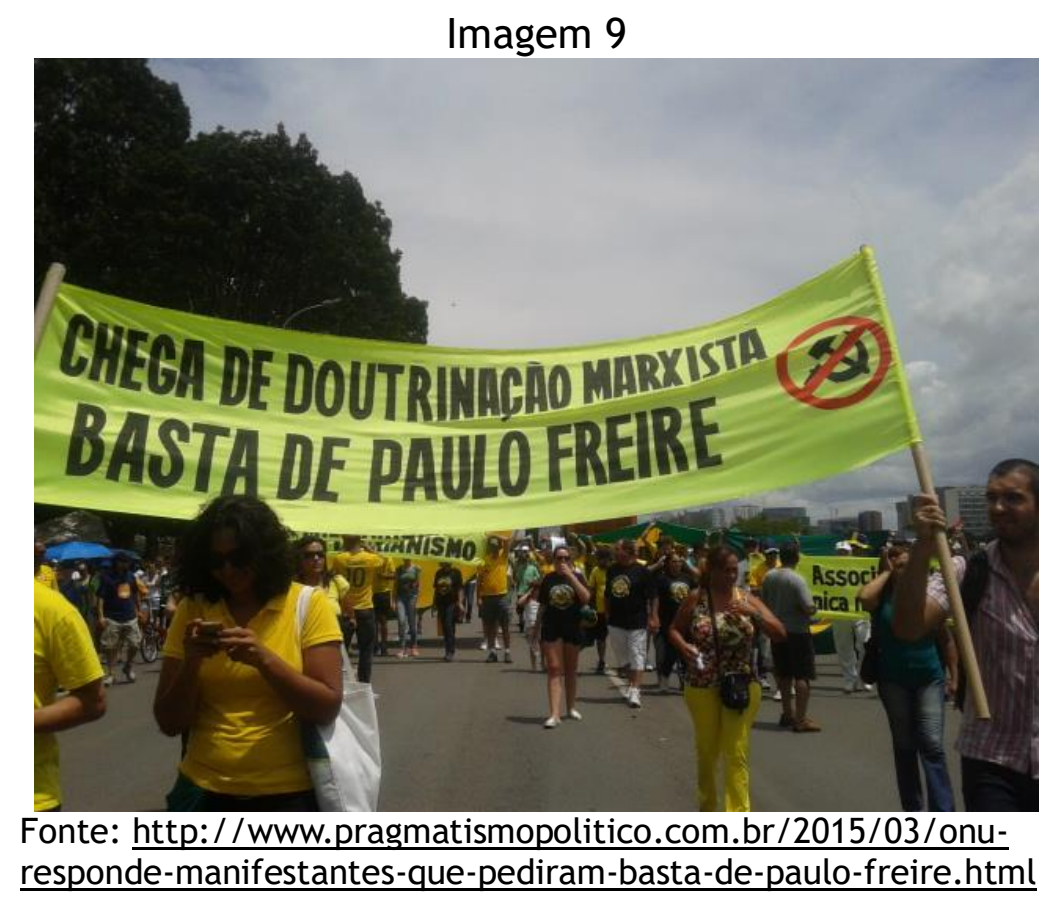

Paulo Freire aqui é mostrado de forma negativa, "Basta de Paulo Freire", revelando sua face "marxista". Na verdade, denunciando e 


\section{periferio}

demonizando, mais do que "revelando". Desmontar o caráter calunioso da faixa não é difícil. Não vamos nos deter nessa questão. Gostaríamos de assinalar apenas o caráter unilateral e acusatório da mensagem, que pretende manchar a imagem de respeitabilidade e credibilidade adquirida por Paulo Freire como educador, acusando-o de "comunista" e, como tal, um doutrinador, um educador de má-fé e prejudicial. A palavra "comunista" não aparece, mas a ideia está presente na icônica imagem da foice e do martelo, aqui marcada pelo sinal da proibição. Como se sabe, Paulo Freire nunca negou a influência de Marx no seu pensamento. Embora, para muitos dos seus críticos, as categorias da economia política não se fazem tão presentes na sua "pedagogia do oprimido", subsistindo a dúvida, portanto, se a identidade marxista de Paulo Freire é assim tão apropriada (ou, pelo menos, até que ponto é pertinente). A verdade é que a afirmação sobre o marxismo de Paulo Freire é motivo para uma discussão, não se trata de uma conclusão sumária como afirma a faixa feita contra ele. Sobre ser comunista, ele mesmo já declinou dessa associação. Quando secretário municipal de educação de São Paulo, entrevistado no programa de Serginho Groisman, na TV Cultura, perguntado sobre se considerava um educador comunista, disse que não era anticomunista, mas disse que comunista também não era, dizendo que acreditava no "socialismo" 4 E, por outro lado, bem longe da imagem de um comunista ateu, sempre manifestou, já afirmamos, seu atravessamento cristão. Os autores da faixa não estavam, é claro, interessados nas ambivalências e contradições do seu pensamento. 0 importante era caracterizá-lo de tal modo de forma negativa para constranger sua influência entre os educadores.

A faixa "Basta de Paulo Freire" foi apresentada em uma das manifestações, em março de 2015, contra a então presidenta Dilma Rousseff, que terminou sofrendo impeachment no ano seguinte. Conjugado com o "fora Dilma", assistimos (e continuamos assistindo...) a uma vigorosa mobilização de

${ }^{4} \mathrm{Cf}<$ https://www.youtube.com/watch?v=Zx-3WVDLzyQ\&feature=youtu.be> Acesso: 20 ago 2017 




grupos ultraconservadores com pautas reacionárias. Entre elas, dirigidas à educação. A campanha contra Paulo Freire na passeata contra Dilma representa, portanto, a confluência dessas ideias, condenação dos governos petistas e de toda a agenda mais progressista para a educação após a chegada de Lula à presidência: derrubar Dilma e sepultar também o legado de Paulo Freire. E aí não se pode especialmente ignorar toda a articulação do movimento Escola Sem Partido para silenciar alunos e professores nas escolas. Paulo Freire representa, com a proposta de uma educação dialógica e transformadora, exatamente o oposto do silêncio sobre política e sociedade que o Escola Sem Partido pretende impor. A campanha insidiosa da faixa "Basta de Paulo Freire" pretende criar uma imagem extremamente negativa de Paulo Freire, comparável a de condenado criminoso, para afastá-lo das ideias e projetos para a educação no país. Observamos que em qualquer fórum aberto sobre Paulo Freire na internet, encontramos, entre as posições discutidas, fortemente presentes as imagens mais caricaturais do seu pensamento, uma representação absolutamente disforme a propósito do que disse, escreveu e representa seu legado.

As duas últimas imagens que selecionamos, 10 e 11, são distintas das anteriores porque foram feitas exclusivamente para a internet. Na verdade, são imagens preexistentes de Paulo Freire que sofreram uma intervenção para um tipo de uso característico nas redes sociais, como o Facebook, mas também o Instagram e o WhatsApp. 


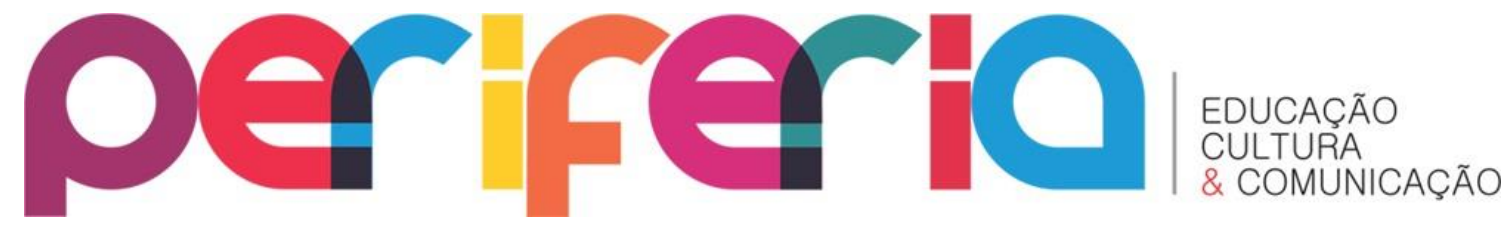

Imagem 10

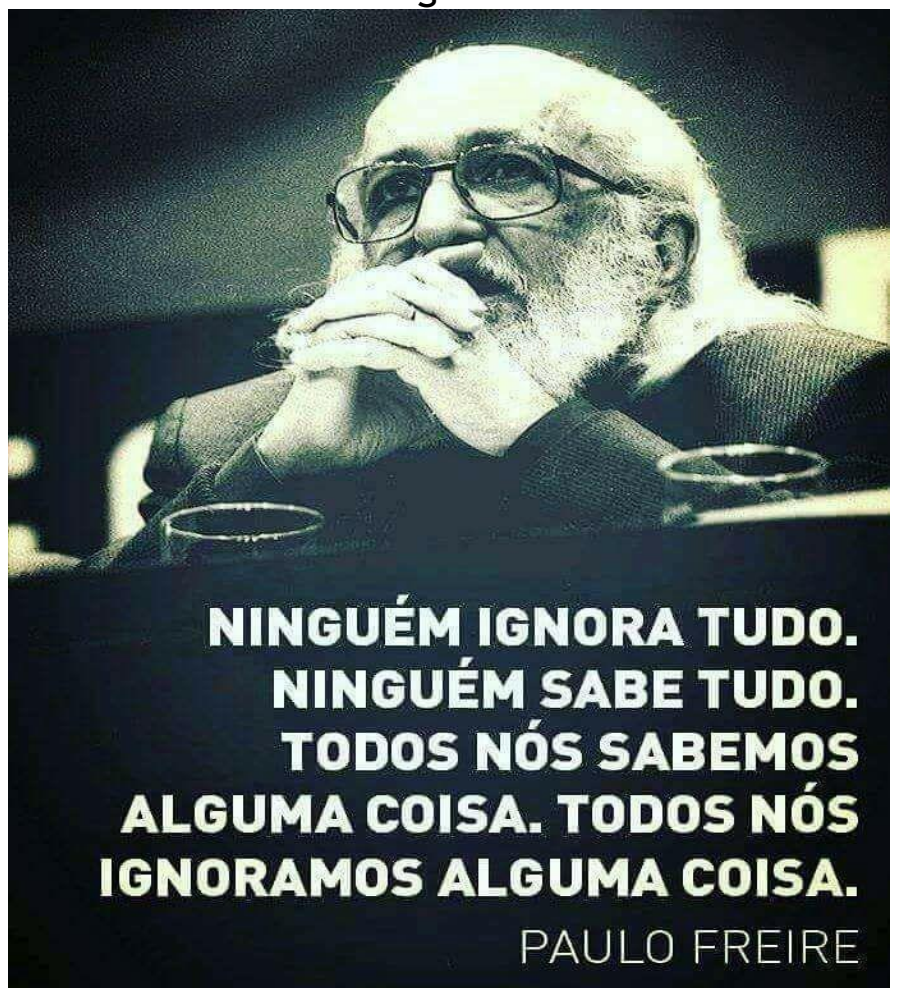

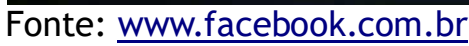

Imagem 11

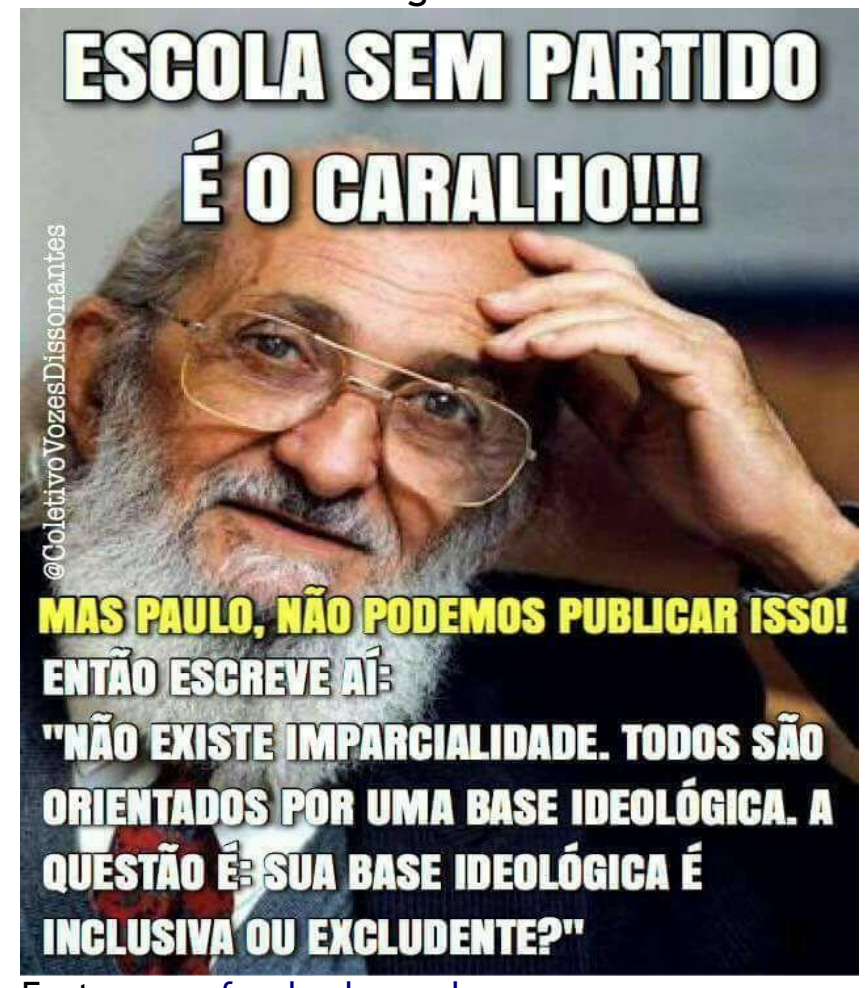

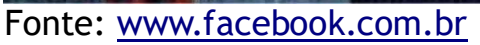




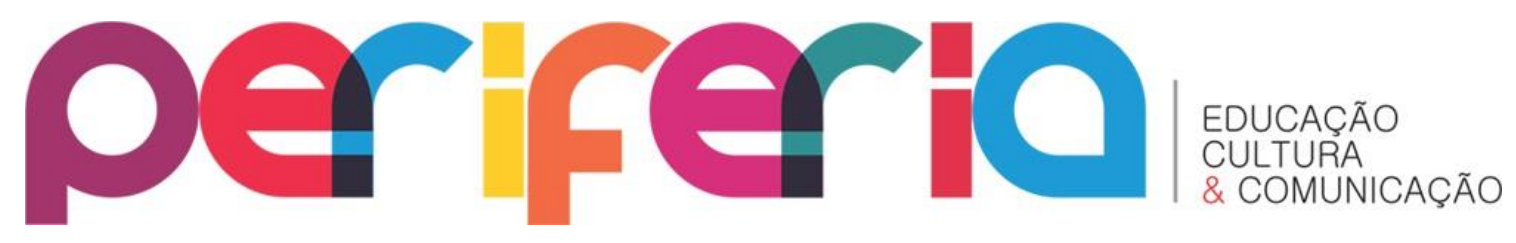

São imagens feitas, sobretudo, para compartilhamento e difusão súbita e viral. A imagem 10 é uma "pílula de sabedoria" freiriana. Compondo a imagem, retrato e uma passagem selecionada de sua obra, destacada como um aforismo. Comparada com a seguinte, é uma fórmula de comunicação mais tradicional usada em uma mídia atual. A imagem 11, também uma composição de retrato mais texto, contém um elemento bem mais acentuado do tipo de comunicação que se desenvolve hoje nas redes sociais quando se trata da abordagem de um tema polêmico e que divide a opinião dos internautas. 0 conteúdo, mais ácido e pulsante, procura situar Paulo Freire no contexto imediato do debate educacional no país. A sugestão, claro, é que Paulo Freire seria capaz de uma recusa impaciente e brutal do movimento Escola Sem Partido. Mas quem poderia imaginar Paulo Freire dizendo um palavrão? Bom, para isso temos a sua "tradução" em um pensamento já conhecido, mas as duas declarações, afinal, querem dizer a mesma coisa. É a proposta desse tipo de transferência entre dois pequenos textos, um mais ousado e direto e a sua versão "polida", na verdade, a original. É uma imagem mais provocante e interativa que a primeira.

As duas imagens são memes que se espalham rapidamente entre os usuários da rede e são demonstrativas da mais popular duplicação e recriação da figura de Paulo Freire na contemporaneidade, através das pessoas comuns, na internet. Não é a imagem feita por um fotógrafo ou artista, trata-se de um reuso de imagens já disponíveis. Ou, se olharmos de outra maneira, são representações produzidas por artistas capazes de samplear imagens já conhecidas criando outras. Do mesmo modo que os DJs fazem música. Com os memes, Paulo Freire parece um personagem mais sagaz e ligado do que a figura do educador rural da sua experiência original como alfabetizador. Imagem de um Paulo Freire que fala grosserias, distante até da imagem plácida que imaginou para si como a sua última exibição.

Retornamos agora a nossa segunda epígrafe: “Como as imagens são usadas? $\mathrm{O}$ que fazemos com as imagens? $\mathrm{O}$ que as imagens fazem com a gente? Faz até mesmo sentido falar da imagem?” Estéril imaginar a presença 


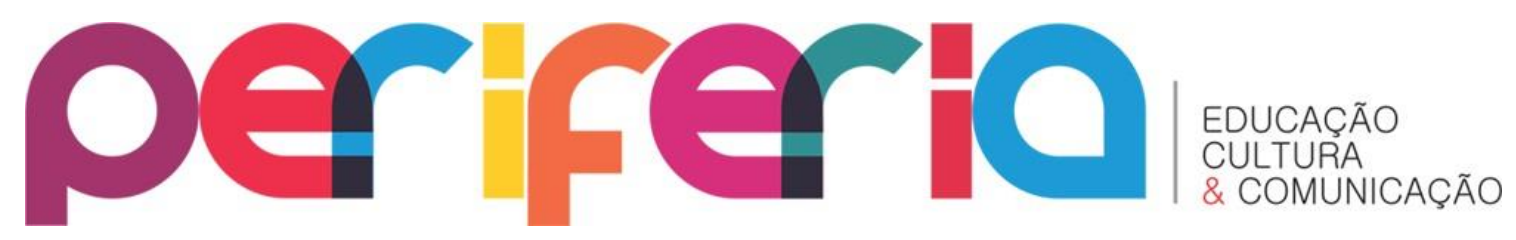

contemporânea de Paulo Freire sem suas imagens virtuais. Será que estamos ainda longe de assistir a uma palestra apresentada por um holograma de Paulo Freire? Não é improvável que aconteça um dia, imaginamos. 0 fato é não nos parece mais possível recuperar Paulo Freire da trama das tantas imagens que procuram definir sua identidade como pessoa e educador. Trabalhamos aqui com algumas poucas imagens, mas são muito mais, tecendo uma existência que não cessará tão cedo, acreditamos. Constituem sucessivas e irrefreáveis reproduções que mais fazem Paulo Freire escapar do que conseguem acertam sua figura. Quando Christoph Wulf (2013, p. 21) pergunta sobre o sentido ou não de falar da imagem refere-se à imagem digital, ou seja, se elas ainda são imagens. "Imagens digitais não estão, em nenhuma medida, baseadas em impressões físicas", observa. Interessante. Quais imagens de Paulo Freire ainda guardam relação analógica com ele? São tantos os seus retratos, Paulo Freire é uma figura sem futuro previsível. As informações transferidas por suas imagens não são absolutas. Mesmo digital, não parece fácil a captura de Paulo Freire. De fato, existem imagens de Paulo Freire? Haveria melhor legado para um educador do que a dúvida sobre a sua reprodução? Não é a sua maior liberdade como educador?

\section{REFERÊNCIAS}

FREIRE, P.. Educação como prática da liberdade. $22^{a}$ ed. São Paulo: Paz e Terra, 2004.

. Com indisfarcável brilho nos olhos. In: Pedagogia da tolerância. São

Paulo: Ed. UNESP, 2004. p. 319-329

FREIRE, P.; GUIMARÃES, S. Aprendendo com a própria história II. São Paulo, Paz e Terra, 2000.

JOLY, M. Introdução à análise da imagem. Campinas: Papirus, 1996.

PILLAR, A. D. (Org.). A educação do olhar no ensino das artes. Porto Alegre: Mediação, 2011. (6. ed. atual. Ortog.) 


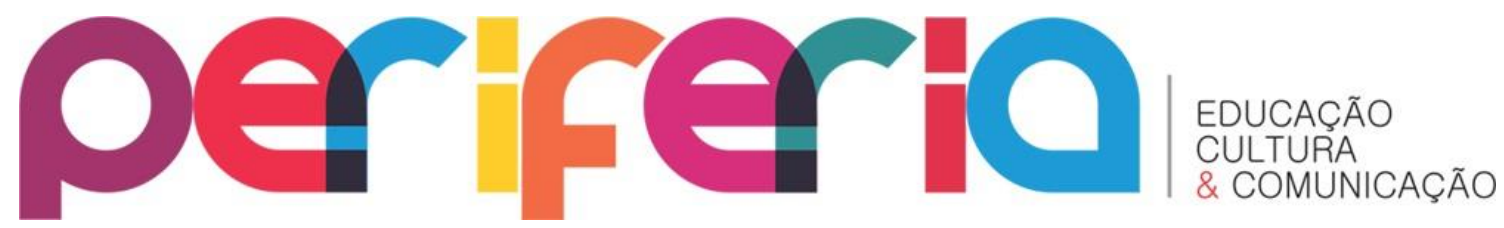

A educação do olhar no Ensino da Arte. In: BARBOSA, A. M. T. B. Inquietações e mudanças no ensino da arte. 2. ed. São Paulo: Cortez, 2003, p. 71-82.

VICENTE, T. A. de S. Metodologia da análise de imagens. Revista Contracampo. Programa de Pós-Graduação em Comunicação da Universidade Federal Fluminense. Niterói: n. 4, p. 147-158, 2000,

WULF, C. Homo Pictor: imaginação, ritual e aprendizado mimético no mundo globalizado. São Paulo: Hedra, 2013. 